O. G. Reznikova, A. B. Darintseva,

I. B. Murashova

Chemical Technology Institute, 28 Mira street, 620002 Ekaterinburg

Phone: +7(343) 3754463;

E-mail: a.b.darintseva@ustu.ru

\title{
About the stabilization of the dendritic structure of GG brand copper powder
}

In industry copper powder is recieved under constant current load. Surface roughening occurs during evolution of the dendritic particles. It is suggested to create a new impulse of current equal to the initial current density of $3200 \mathrm{~A} / \mathrm{m}^{2}$ in order to obtain uniform structure of the precipitate. Current load was evaluated by the result of chronopotentiometry research of the dynamics of the dendritic precipitate on cylindrical electrode. Four-impulse galvanostatic electrolysis was investigated for the copper powder GG. New current impulse shifts the electrode potential to the cathodic area, crystallization process flows more rapidly.

* This work was done under financial support from RFBR № 11-03-002296.

(C) Reznikova 0. G., Darintseva A. B., Murashova I. B., 2015

\section{Introduction}

Electrolytic metal powders are widely used in many industries. Metal powders allow manufacturing by powder metallurgy products with unique characteristics ${ }^{1}$. In the industrial production of metal powders it is carried out while maintaining a constant current load which is several times higher than the limit. During the industrial electrolysis dendritic sediment was crystallized on cathodes. Properties of the finished powders depend on postelectrolysis processing: grinding, sieving, but the main characteristics of the powder are laid at the stage of electrolysis.

In galvanostatic electrolysis, sufficiently small particles are formed on the electrode surface that further either stop their growth or develop into dendrites. As the surface of dendritic sediment increases the diameter of the electrode with the sediment $y$ thickness, cathode overvoltage of metal release is reduced ${ }^{2}$. With the decrease in cathode overvoltage diffusion limitations are reduced, the growth of dendritic sediment is suspended. It was stated ${ }^{3}$ with the help of studies that achieving the field voltage equalling to 0,54-0,59 B leads to crystallization at the growth in front of solid globules, which are then fused to form a solid crust of a chained sediment. It is offered at certain points in time to submit a new electrode current pulse equal to the initial current density on the electrode. Increasing the 
surge will lead to more intensive development of cathode surface on the growth front the thin branched particles will again start to crystallize ${ }^{4}$. With the development of dendritic sediment on the growth front, overvoltage will fall again; then it is necessary to submit a new current pulse on to the electrode.

\section{The experimental part}

Studies were carried out in an electrolyte solution to obtain a copper powder brand GG, which contains $23 \mathrm{~g} / \mathrm{C} \mathrm{Cu}^{2+}$ and $150 \mathrm{~g} / 1 \mathrm{H}_{2} \mathrm{SO}_{4}$. Limiting stationary current density was determined using a potentiostat IPC-Pro by chrono-voltammetry with linear variation of the potential (Fig. 1).

According to the calculations steadylimit-stationary current density is $i_{\mathrm{PR} . \mathrm{ST}}=370 \mathrm{~A} / \mathrm{m}^{2}$. Then we define the current load, which must be maintained at an electrode of diameter of $2.6 \mathrm{~mm}$ and a height of $8 \mathrm{~mm}$. Electrolysis was carried out under laboratory conditions with a current density equal to the factory one, which is $3200 \mathrm{~A} / \mathrm{m}^{2}$, while it was necessary to set the current $\mathrm{I}=226 \mathrm{~mA}$. In the course of galvanostatic electrolysis, a continuous recording of growth of dendritic sediment was conducted with a video camera PanasonicSDR-S150GC-S. Electrolysis results are shown in Fig. 2.

When the current is on, overvoltage abruptly shifts to more negative values, followed by a period of small oscillations

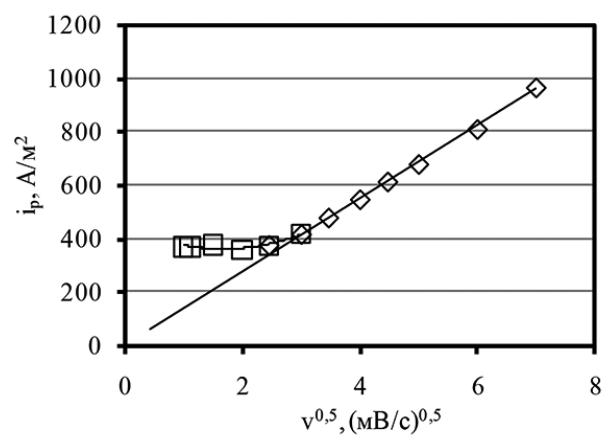

Fig.1. Dependence for the determination of the maximum steady-state current density of the potential, which is followed by a period of large fluctuations. At the time of stopping of active growth of dendritic sediment (1440), overvoltage is significantly reduced. The diameter of the electrode with sediment is increasing until the overvoltage reaches the area of about 0.6 $\mathrm{V}$, which is close to the precipitate ceases to lengthen.

Actively growing dendritic precipitate was decided to divide into 4 equal lengths of 6 minutes each. Through stated interval new current pulse was applied to the electrode, equal to the initial current density. For determining the magnitude current pulse, dynamics studies were conducted at two growth precipitate pulses of current (Fig. 3), three (Fig. 4) and four (Fig. 5).

Each subsequent pulse of current was calculated from the results of processing video precipitate dendritic growth. Current value was determined by the formula

$$
I=i \cdot\left(d_{0}+2 y\right)_{t} \cdot H,
$$

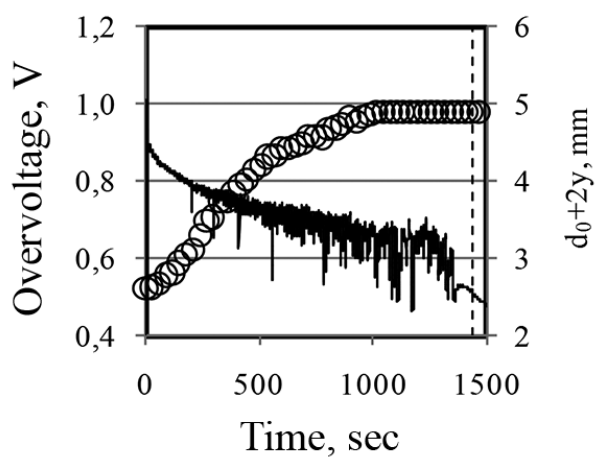

Fig. 2. Dynamics of changes in the diameter of the electrode with sediment $(\mathrm{O})$ and cathodic overvoltage (line) in the single-pulse electrolysis 


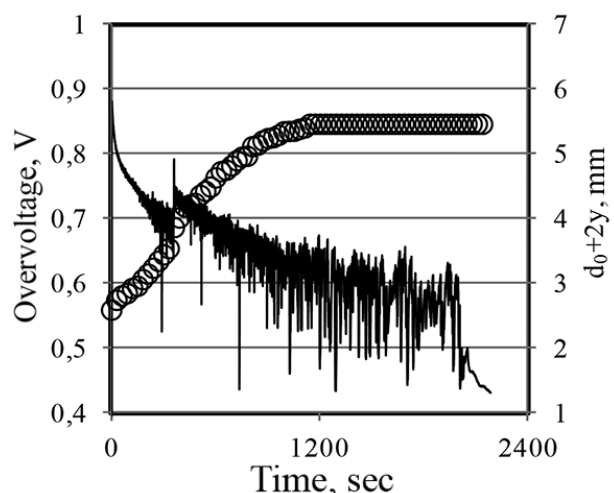

Fig. 3. Changing the diameter of the electrode with sediment $(\mathrm{O})$ and cathodic overvoltage

(line) during the two-pulse electrolysis

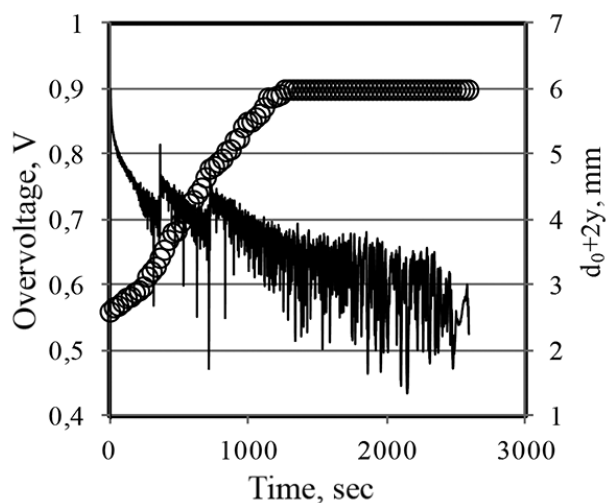

Fig. 4. Changing the diameter of the electrode with the precipitate $(\mathrm{G})$ and cathode overvoltage (line) in the three-pulse electrolysis

creased from 0.68 to $0.79 \mathrm{~V}$. When the same pulse electrolysis is used, the period of active growth was increased and amounted to 2100; the diameter of the electrode with a deposit at the time of stopping the process has reached $5.5 \mathrm{~mm}$.

Two-pulse electrolysis further increases the time of active growth of dendritic solid (Fig. 4), the diameter of the pellet electrode is also increasing. According to the video processing of the growth of the dendritic precipitate after 6 minutes and after the second pulse current electrode had the diameter of $4.91 \mathrm{~mm}$; therefore, the value of the third current pulse is $455 \mathrm{~mA}$.

Galvanostatic electrolysis with three pulses of current (Fig. 4) increases the growth of the active sludge to 2500 , the diameter of the electrode with the precipitate at the time the process is stopped is $6 \mathrm{~mm}$. The magnitude of the current load on the fourth pulse is equal to $I=531 \mathrm{~mA}$. Amperogram of four-pulse electrolysis is shown in Fig. 6.

Duration of four-staged electrolysis (Fig. 5) before the reset of the surge was $3900 \mathrm{sec}$; diameter of electrode with pre- 


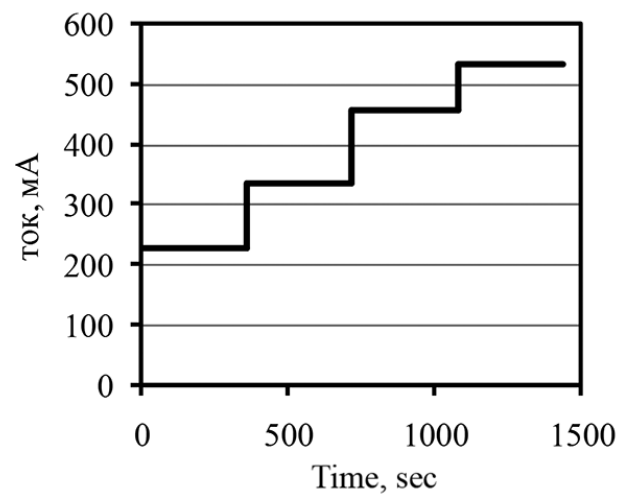

Fig. 6. Amperogram of four-pulse electrolysis

cipitation has increased to $6.6 \mathrm{~mm}$.

Current pulse increases the cathode overvoltage; dendritic precipitate at the time of switching current begins to develop more actively. Increasing the current load leads to the rapid development of dendritic precipitate in height, which is characterized according to bend $d_{0}+2 y$ (Fig. 3-5).

To study the structure of the sediment there were carried dendrit micrographs of thin cross-section of the electrode with the sediment (Fig. 7), made with a digital metallographic microscope AltamiMET $1 \mathrm{M}$.

At the time of switching current pulse, more subtle elements of sediment are

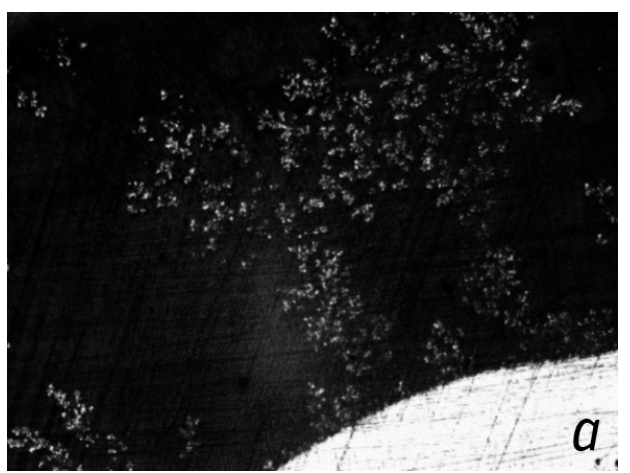

formed at the growth front. Fig. 7b shows a photograph of $1.5 \mathrm{~min}$ after the third switching current.

Cylindrical electrode with dendrit sediment is 3D electrode. The surface of the three-dimensional electrode works unevenly, electrochemical process occurs on the outer surface of the active electrode. Speed of electrode process decreases from the outer surface into the thickness of the sediment. The penetration depth $\lambda$ is the characteristic length of the distance which the speed of the process is reduced by 2.7 times.

The penetration depth of the electrode process was calculated from the results of processing of the chronopotentiograms and videos dendritic growth of sediment (Fig. 8).

When the new current pulse is sent, overvoltage increases abruptly but does not reach its maximum value at the previous pulse. This phenomenon is due to the different penetration depth of electrochemical process in the dendritic layer of sediment.

The depth of penetration is defined as half the difference of electrode diameter with sediment at the maximum overvoltage when switching less electrode diam-

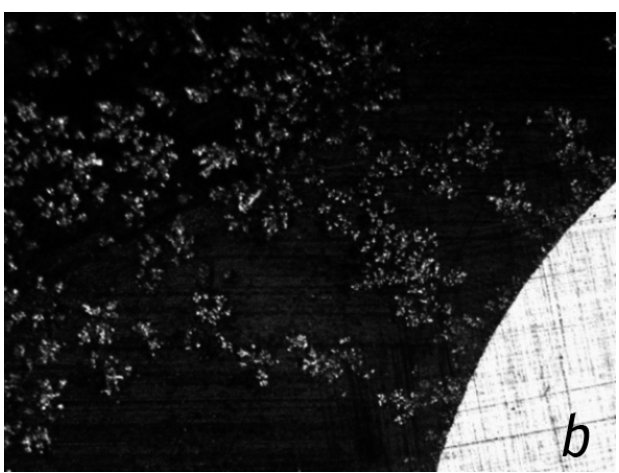

Fig. 7. Micrographs of a cross section of the electrode with dendritic precipitate.

Electrolysis time, min: $a-18 ; b-19.5$. increase x 10 


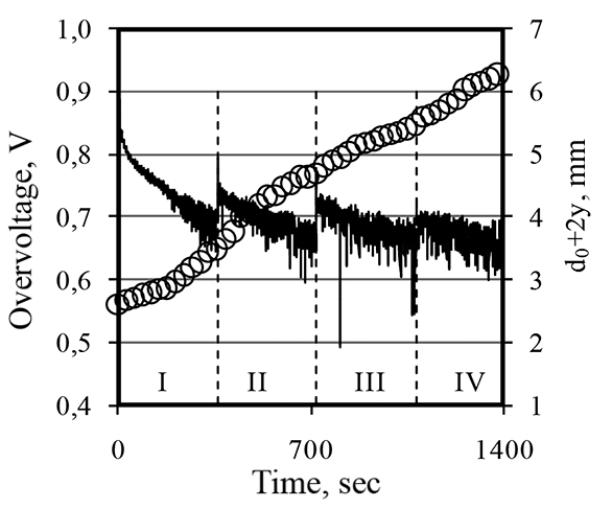

Fig. 8. Chronopotentiogram (line) and the diameter of the electrode with the precipitate (a) at four-pulse electrolysis. The numbers in the diagram show the number of periods

\section{Results and discussion}

Increasing the load current to create the initial current density on the growth front of sediment raises cathode overvoltage, accelerates the process of elongation of dendrites and again leads to the crystal- eter with sediment, corresponding to the value of surge suppressors, equal to the maximum by setting the previous current pulse. For a given current pulses $\lambda$ was calculated. At current load of $335 \mathrm{~mA}$

$\lambda_{335}=0,5 \cdot(3,48-2,68)=0,4 \mathrm{~mm}$;

at $455 \mathrm{~mA}$

$\lambda_{455}=0,5 \cdot(4,68-3,49)=0,595 \mathrm{~mm}$;

at $531 \mathrm{~mA}$

$\lambda_{531}=0,5 \cdot(5,47-4,74)=0,365 \mathrm{~mm}$.

Unambiguous results in penetration depth values could not be obtained. At the same conductivity of electrolyte solution, the specific surface area of the electrode displaced electro-chemical process on an outer surface of a porous electrode in the case of a larger current ${ }^{5}$.

lization of thin branched particles. Using this mode of the process a significant increase in sediment build-up period can be achieved, while maintaining its structure.

1. Neikov O. D., Nabojchenko S. S., Murashova I. B., Gopienko V. G., Frishberg I. V., Lotsko D. V. Handbook of non-ferrous metal powders. Technologies and applications. London, N-Y. Amsterdam: Elsevier 2009, 634 p.

2. Murashova I. B., Darinzeva A. B., Rudoy V. M. Analysis of growth dynamics of dendrite copper deposit in copper sulfate solutions under the galvanostatic conditions. Russian J. of Electrochemistry 2010;46(6):611-618. DOI: 10.1134/ S10231935100600300.

3. Murashova I. B., Sokolovskaya E. E., Lebed' A. B., Yun' A. A., Bodrova M. L. The formation of dendritic precipitation in the production of electrolytic copper powder. Zvetnye metally 2007; 10:46.

4. Darinzeva A. B., Osipova M. L., Murashova I. B. The regulation patterns of dendritic copper sludge gg during electrolysis by changing the cathode surface of the cell. Vestnik Kazanskogo technologicheskogo universiteta 2012;15:129.

5. Ksenzhek O. S., Shembel' E. M., Kalinovsky E. M., Shustov V. A. Electrochemical processes in porous matrixes. Kiev: Vysshaya shkola; 1983, 220 p. 


\author{
О. Г. Резникова, А. Б. Даринцева, \\ И. Б. Мурашова
}

Химико-технологический институт, Мира, 28, 620002, Екатеринбург. Тел.: (343) 375-44-63;

E-mail:a.b.darintseva@urfu.ru

\title{
0 стабилизации дендритной структуры порошка меди марки GG*
}

В промышленности порошок меди получают при поддержании постоянной токовой нагрузки. По мере развития дендритного осадка происходит огрубление поверхности. Для получения более равномерного по структуре осадка предложено через определенные промежутки времени задавать новый импульс тока, равный исходной плотности тока 3200 A/м². Токовую нагрузку определяли по результатам хронопотенциометрических исследований динамики развития дендритного осадка на цилиндрическом электроде. Проведено исследование четырехимпульсного гальваностатического электролиза для порошка меди марки GG. Новый импульс тока сдвигает потенциал электрода в более отрицательную область, процесс кристаллизации металла начинает протекать более интенсивно.

* Работа выполнена при финансовой поддержке РФФИ грант № 11-03-00226.

(C) Резникова О. Г., Даринцева А. Б., Мурашова И. Б., 2015

\section{Введение}

Электролитические порошки металлов находят широкое применение во многих областях промышленности. Порошки металлов позволяют изготавливать методами порошковой металлургии изделия с уникальными свойствами [1]. В промышленности получение порошков металлов проводят при поддержании постоянной токовой нагрузки, в несколько раз превышающей предельную. В ходе промышленного электролиза на стержневых катодах кристаллизуется дендритный осадок. Свойства готовых порошков зависят от послеэлектролизной обра- ботки: размол, рассев, но основные характеристики порошка закладываются именно на стадии электролиза.

При гальваностатическом электролизе на поверхности электрода формируются достаточно мелкие частицы, которые в дальнейшем либо останавливают свой рост, либо развиваются в дендриты. По мере развития поверхности дендритного осадка увеличивается диаметр электрода с осадком толщиной $y$, уменьшается катодное перенапряжение выделения металла [2]. По мере уменьшения катодного перенапряжения снижаются диффузи- 
онные ограничения, рост дендритного осадка приостанавливается. Исследованиями установлено [3], что достижение области перенапряжения, равной 0,54-0,59 В, приводит к кристаллизации на фронте роста сплошных глобул, которые затем срастаются, образуя сплошную корку закованного осадка. Предлагается в определенные моменты времени на электрод подавать новый импульс тока, равный исходной

\section{Экспериментальная часть}

Исследования проводили в растворе электролита для получения порошка меди марки $\mathrm{GG}$, который содержит 23 г/л $\mathrm{Cu}^{2+}$ и 150 г/л $\mathrm{H}_{2} \mathrm{SO}_{4}$. Предельную стационарную плотность тока определяли с помощью потенциостата IPCPro методом хроновольтамперометрии при линейном изменении потенциала (рис. 1).

Согласно расчетам предельная стационарная плотность тока $i_{\text {пр.ст }}=$ $=370 \mathrm{~A} / \mathrm{M}^{2}$. Затем определяем токовую нагрузку, которую необходимо поддерживать на электроде диаметром 2,6 мм и высотой 8 мм. Электролиз в лабораторных условиях проводили при плотности тока, равной завод-

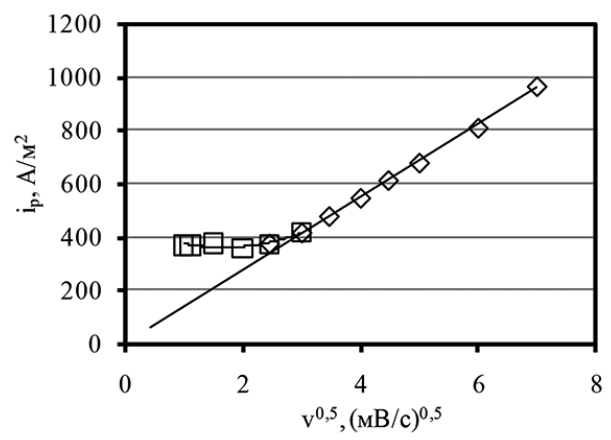

Рис. 1. Зависимость для определения предельной стационарной плотности тока плотности тока на стрежневом электроде. Увеличение перенапряжения приведет к более интенсивному развитию катодной поверхности, на фронте роста вновь начнут кристаллизоваться тонкие разветвленные частицы [4]. По мере развития дендритного осадка на фронте роста перенапряжение будет снова снижаться, тогда на электрод необходимо подать новый импульс тока.

ской $3200 \mathrm{~A} / \mathrm{M}^{2}$, при этом необходимо было задавать ток $I=226$ мА. В ходе гальваностатического электролиза проводили непрерывную видеозапись роста дендритного осадка с помощью видеокамеры PanasonicSDR-S150GC-S. Результаты электролиза представлены на рис. 2.

При включении тока перенапряжение скачком сдвигается в область более отрицательных значений, затем следует период малых колебаний потенциала, который сменяется периодом больших колебаний. К моменту остановки активного роста дендритного осадка

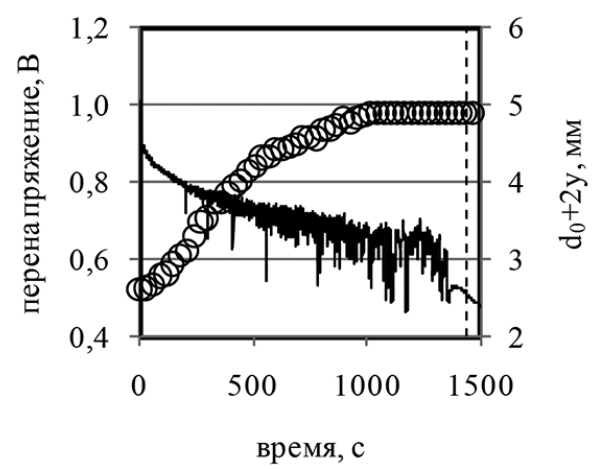

Рис. 2. Динамика изменения диаметра электрода с осадком $(\mathrm{O})$ и катодного перенапряжения (линия) в ходе одноимпульсного электролиза 
(1440 c) перенапряжение резко снижается. Диаметр электрода с осадком увеличивается до тех пор, пока перенапряжение не достигает области около 0,6 В, вблизи которой осадок перестает удлиняться.

Время активного роста дендритного осадка было решено разбить на 4 равных отрезка по 6 мин. каждый. Через указанный интервал времени на электрод подавать новый импульс тока, равный начальной плотности тока. Для определения величины импульса тока были проведены исследования динамики роста осадка при двух импульсах тока (рис. 3), при трех (рис. 4) и при четырех (рис. 5).

Каждый следующий импульс тока рассчитывали исходя из результатов обработки видеозаписи роста дендритного осадка. Величину тока определяли по формуле

$$
I=i \cdot\left(d_{0}+2 y\right)_{t} \cdot H,
$$

где $i$ - исходная плотность тока, равная заводской $3200 \mathrm{~A} / \mathrm{M}^{2} ;\left(d_{0}+2 y\right)_{t}$ - диаметр электрода с осадком к моменту переключения тока; $H$ - высота электрода, которую принимали постоянной, рав-

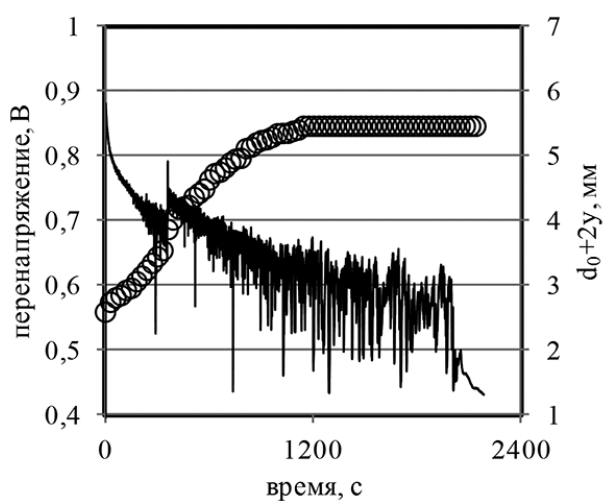

Рис. 3. Изменение диаметра электрода с осадком $(\mathrm{O})$ и катодного перенапряжения (линия) в ходе двухимпульсного электролиза ная 8 мм. При токе 226 мА через 6 мин. от начала электролиза диаметр электрода составил 3,73 мм (рис. 2). На втором импульсе при начально заданной плотности тока необходимо подавать ток $I=335 \mathrm{MA}$.

В момент переключения тока с 226 на 335 мА перенапряжение увеличилось скачком с 0,68 до 0,79 В

При одноимпульсном электролизе период активного роста увеличился и составил 2100 с, диаметр электрода с осадком к моменту остановки процесса достиг 5,5 мм.

Двухимпульсный электролиз еще больше увеличивает время активного роста дендритного осадка (рис. 4), при этом диаметр электрода с осадком также увеличивается. Согласно результатам обработки видеозаписи роста дендритного осадка через 6 мин. после второго импульса тока диаметр электрода с осадком составил 4,91 мм, следовательно, величина третьего импульса тока составляет 455 мА.

Гальваностатический электролиз с тремя импульсами тока (рис. 4) увеличивает время активного роста осадка

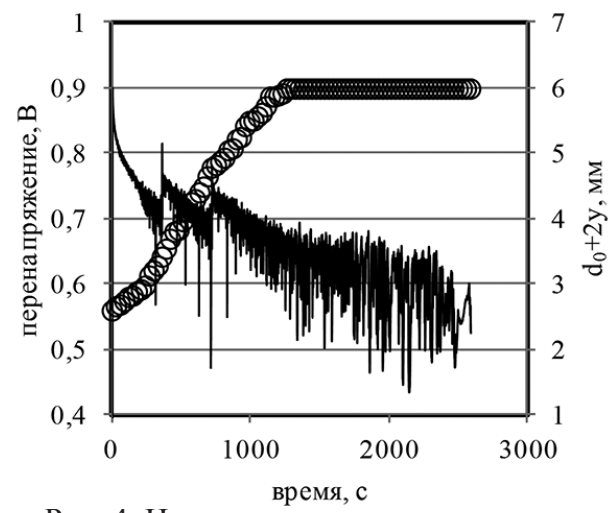

Рис. 4. Изменение диаметра электрода с осадком $(\mathrm{O})$ и катодного перенапряжения (линия) в ходе трехимпульсного электролиза 
до 2500 с, диаметр электрода с осадком к моменту остановки процесса составляет 6 мм. Величина токовой нагрузки на четвертом импульсе равна $I=531$ мА. Амперограмма для четырехимпульсного электролиза представлена на рис. 6.

Продолжительность четырехступенчатого электролиза (рис. 5) до сброса перенапряжения составила 3900 с, диаметр электрода с осадком увеличился до 6,6 мм.

Импульс тока увеличивает катодное перенапряжение, дендритный осадок в момент переключения тока начинает более активно развиваться. Увеличение токовой нагрузки приводит к быстрому развитию дендритного осадка в высоту, что характеризуется перегибами зависимости $d_{0}+2 y$ (рис. 3-5).

Для исследования структуры дендритного осадка выполнены микрофотографии шлифов поперечного среза электрода с осадком (рис. 7), выполненные с помощью цифрового металлографического микроскопа AltamiMET 1M.

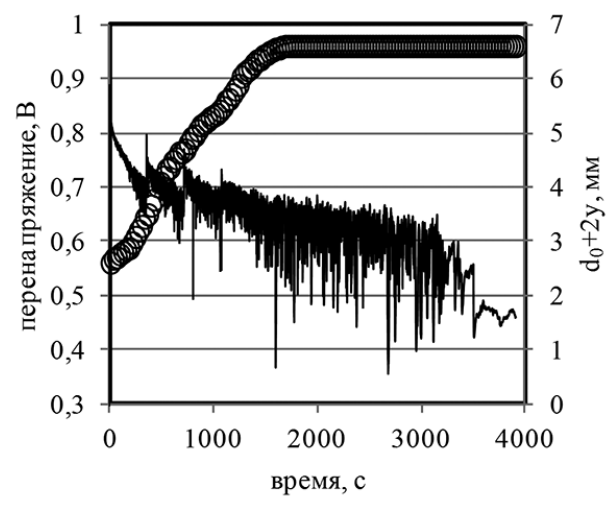

Рис. 5. Изменение диаметра электрода с осадком $(\mathrm{O})$ и катодного перенапряжения (линия) в ходе четырехимпульсного электролиза
В момент переключения импульса тока на фронте роста образуются более тонкие элементы осадка. На рис. $7 б$ представлена фотография через 1,5 мин. после третьего переключения тока.

Цилиндрический электрод с дендритным осадком представляет собой трехмерный электрод. Поверхность трехмерного электрода работает неравномерно, электрохимический процесс протекает активно на внешней поверхности электрода. Скорость электродного процесса снижается от внешней поверхности вглубь толщины осадка. Глубина проникновения $\lambda$ - это характеристическая длина на расстоянии которой скорость процесса снижается в 2,7 paза.

Глубину проникновения электродного процесса рассчитывали исходя из результатов обработки полученных хронопотенциограммы и видеозаписи роста дендритного осадка (рис. 8).

При включении нового импульса тока перенапряжение скачком увеличивается, но не достигает максимального значения при предыдущем импульсе.

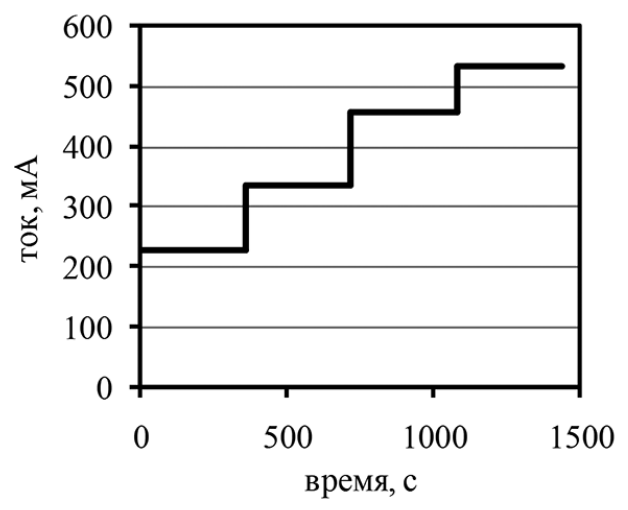

Рис. 6. Амперограмма четырехимпульсного электролиза 

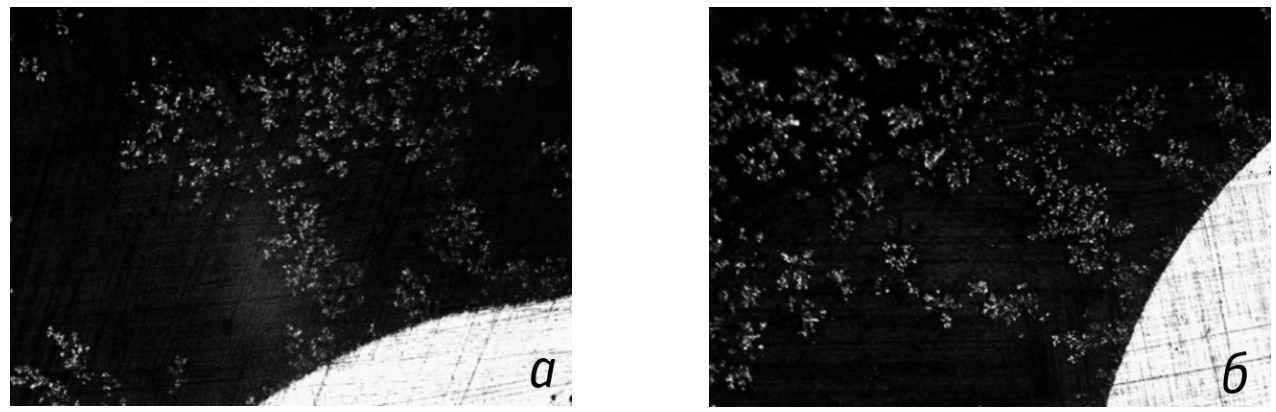

Рис. 7. Микрофотографии поперечного среза электрода с дендритным осадком. Время электролиза, мин.: $a-18 ; \sigma-19,5$. Увеличение х10

Предположительно, такое явление связано с различной глубиной проникновения электрохимического процесса в слое дендритного осадка.

Глубину проникновения определяли как половину разности диаметра электрода с осадком при максимальном значении перенапряжения в момент переключения за вычетом диаметра электрода с осадком, соответствующий значению перенапряжения, равного максимальному при задании предыдущего импульса тока. Для заданных импульсов тока выполнен расчет $\lambda$. При токовой нагрузке 335 мА

$\lambda_{335}=0,5 \cdot(3,48-2,68)=0,4 \mathrm{~mm}$;

при 455 мА

$\lambda_{455}=0,5 \cdot(4,68-3,49)=0,595 \mathrm{MM}$; при 531 мА

$\lambda_{531}=0,5 \cdot(5,47-4,74)=0,365$ мм.

Однозначных результатов в значениях глубины проникновения получить не удалось. При одинаковой элек-

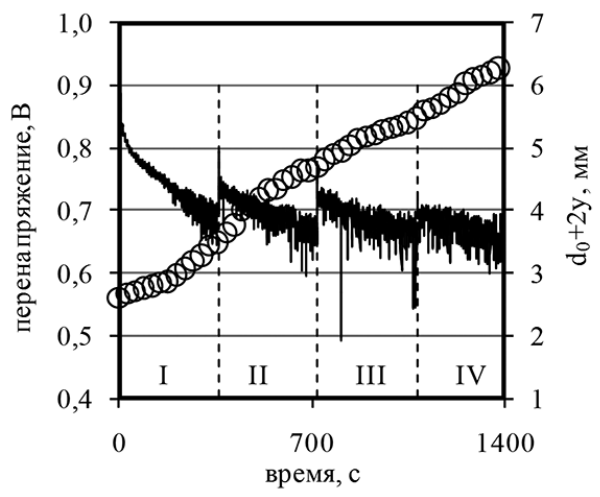

Рис. 8. Хронопотенциограмма (линия) и диаметр электрода с осадком (о) при четырехимпульсном электролизе. Цифрами на диаграмме показаны номера периодов

тропроводности раствора электролита, удельной поверхности электрода электрохимический процесс вытесняется на внешнюю поверхность пористого электрода в случае задания большего тока [5].

\section{Результаты и обсуждение}

Повышение токовой нагрузки до создания первоначальной плотности тока на фронте роста осадка поднимает катодное перенапряжение, ускоряет процесс удлинения дендритов и приводит вновь к кристаллизации тонких разветвленных частиц. Используя такой режим проведения процесса можно добиться значительного увеличения периода наращивания осадка с сохранением его структуры. 
1. Neikov O. D., Nabojchenko S. S., Murashova I. B., Gopienko V. G., Frishberg I. V., Lotsko D. V. Handbook of non-ferrous metal powders. Technologies and applications. London, N-Y, Amsterdam: Elsevier, 2009. 634 p.

2. Мурашова И. Б., Даринцева А. Б., Рудой В. М. Анализ динамики роста дендритного медного осадка в гальваностатических условиях в растворах сульфата меди // Электрохимия. 2010. Т. 46. С. 649.

3. Мурашова И. Б., Соколовская Е. Е., Лебедь А. Б., Юнь А. А., Бодрова М. Л. Формирование дендритных осадков при производстве электролитических медных порошков // Цветные металлы. 2007. № 10. С. 46.

4. Даринцева А. Б., Осипова М. Л., Мурашова И. Б. Регулирование структуры дендритного медного осадка GG в ходе его электролиза изменением катодной поверхности электролизера // Вестн. Казан. технолог. ун-та. 2012. Т. 15. С. 129.

5. Ксенжек О. С., Шембель Е. М., Калиновский Е. А., Шустов В. А. Электрохимические процессы в пористых матрицах. Киев: Высшая школа, 1983. 220 с.

Рекомендуем при цитировании данно статьи следующую ссылку: Reznikova O. G., Darintseva A. B., Murashova I. B. About the stabilization of the dendritic structure of GG brand copper powder // Chimica Techno Acta. 2015. Vol. 2. № 2. P. 116-126. 